\title{
Contracaecum pelagicum and C. plagiaticium (Nematoda: Anisakidae) infection in Magellanic penguins (Sphenisciformes: Spheniscidae) on the coast of Rio de Janeiro State ${ }^{1}$
}

\author{
Sabrina D.E. Campos ${ }^{2 *}$, Bárbara Bianca N. Pereira ${ }^{3}$, Salvatore Siciliano ${ }^{4}$, \\ Carlos Henrique C. Costa ${ }^{5}$, Nádia R.P. Almosny ${ }^{6}$ and Beatriz Brener ${ }^{7}$
}

\begin{abstract}
Campos S.D.E., Pereira B.B.N., Siciliano S., Costa C.H.C., Almosny N.R.P. \& Brener B. 2013. Contracaecum pelagicum and C. plagiaticium (Nematoda: Anisakidae) infection in Magellanic penguins (Sphenisciformes: Spheniscidae) on the coast of Rio de Janeiro State. Pesquisa Veterinária Brasileira 33(1):89-93. Departamento de Patologia e Clínica Veterinária, Faculdade de Veterinária Universidade Federal Fluminense, Rua Vital Brazil Filho 64, Vital Brazil, Niterói, RJ 21230-360, Brazil. E-mail: s.destri@gmail.com

The occurrence of infections and the disease induced by Contracaecum plagiaticium and Contracaecum pelagicum in Magellanic penguins, Spheniscus magellanicus Foster. 1781 (Sphenisciformes: Spheniscidae) were reported on the coast of Rio de Janeiro. Parasites of the genus Contracaecum were present in all of the 11 studied animals. Co-infections by Csontracaecum pelagicum and C. plagiaticium were observed in three hosts (27.27\%). Gross lesions included hyperemia of the esophagus and/or stomach in six animals (54.54\%). One of these animals (9.09\%), parasitized by C. plagiaticium, presented a hemorrhagic area in the gastric mucosa. Histopathological findings demonstrated esophagitis with helminthes segments inserted in the epithelium, showing discrete mixed inflammatory infiltrate of heterophils and mononuclear cells. These parasites may be associated with other diseases, implicating in death of the penguins.
\end{abstract}

INDEX TERMS: Magellanic penguin, Contracaecum plagiaticium, Contracaecum pelagicum, pathology.

RESUMO.- [Infecção por Contracaecum pelagicum e $C$. plagiaticium (Nematoda: Anisakidae) em pinguins-de-Magalhães (Sphenisciformes: Spheniscidae) na costa do Estado do Rio de Janeiro.] A ocorrência da infeção e a

\footnotetext{
${ }^{1}$ Received on December 2, 2011.

Accepted for publication on August 3, 2012.

${ }^{2}$ Mestranda, Programa de Pós-Graduação em Clínica e Reprodução Animal, Faculdade de Veterinária, Universidade Federal Fluminense (UFF), Rua Vital Brazil Filho 64, Vital Brazil, Niterói, RJ 24230-340. * Corresponding author: s.destri@gmail.com

${ }^{3}$ Graduanda em Medicina Veterinária, Faculdade de Veterinária, UFF, Niterói, RJ. E-mail: babinpereira@gmail.com

${ }^{4}$ Grupo de Estudos de Mamíferos e Aves Marinhas da Região dos Lagos (GEMM, Lagos), Escola Nacional de Saúde Pública/Fiocruz, Rua Leopoldo Bulhões 1480, Manguinhos, Rio de Janeiro, RJ 21041-210. E-mail: sal@ensp.fiocruz.br

${ }^{5}$ Centro Estadual de Pesquisa em Sanidade Animal Dr. Geraldo Manhães Carneiro, Empresa de Pesquisa Agropecuária do Estado do Rio de Janeiro (Pesagro-Rio), Alameda São Boa Ventura 770, Fonseca, Niterói, RJ 24120191. E-mail: chcampello@yahoo.com.br

${ }^{6}$ Docente do Departamento de Patologia e Clínica Veterinária, Faculdade de Veterinária, UFF, Niterói, RJ. E-mail: almosny@vm.uff.br

7 Departamento de Microbiologia e Parasitologia, Instituto Biomédico, UFF, Rua Professor Ernani Melo 101, Centro, Niterói, RJ 24210-130. E-mail: brener@vm.uff.br
}

doença induzida por Contracaecum plagiaticium e Contracaecum pelagicum em pinguins-de-Magalhães, Spheniscus magellanicus Foster, 1781 (Sphenisciformes: Spheniscidae), na costa do Rio de Janeiro, foram relatadas. Parasitos do gênero Contracaecum estavam presentes em todos os 11 animais estudados. Co-infecção por Contracaecum pelagicum e C. plagiaticium foi observada em três hospedeiros $(27,27 \%)$. Achados macroscópicos de necropsia incluíram hiperemia do esôfago e/ou estômago em seis animais (54,54\%). Um desses animais (9,09\%), parasitado por $C$. plagiaticium, apresentou área hemorrágica na mucosa gástrica. Os achados histopatológicos demonstraram esofagite com segmento de helminto inserido no epitélio, e discreto infiltrado inflamatório misto com heterófilos e células mononucleares. Estes parasitos podem estar associados a doenças, implicando em morte dos pinguins.

TERMOS DE INDEXAÇÃO: Pinguim-de-Magalhães, Contracaecum plagiaticium, Contracaecum pelagicum, patologia.

\section{INTRODUCTION}

Penguins are considered sentinels of the oceans, thus studies of these birds provide knowledge of the source and in- 
tensity of human impacts over marine habitats in the southern hemisphere (Boersma 2008).

The Magellanic Penguin, Spheniscus magellanicus Foster, 1781 (Sphenisciformes: Spheniscidae) has a pelagic and predatory habit, migrating from its reproductive colonies, through ocean currents, to the Brazilian continental shore to eat. (Ruoppolo et al. 2004, Silva Filho \& Ruoppolo 2007, Serafini et al. 2010). In this route, some specimens may deviate from the group, reaching more distant areas of the Brazilian coast, like Rio de Janeiro State and others beaches, where they are rescued. However, these birds become debilitated and malnourished, and often have infectious or non-infectious diseases, which interfere in the rehabilitation process (Serafini et al. 2010).

Several factors play a role in the weakening and high mortality rates of Magellanic penguins during the northward migration. Some of these factors include non-infectious diseases, oil contamination, capture by fishing nets, trauma and foreign body ingestion (Ellis \& Branch 1994, Fonseca et al. 2001, Mäder et al. 2010). Gastrointestinal parasitosis is a common hygienic-sanitary problem in captive animals, being one of the most important disorders that contribute to the weakening of these birds (Fonseca et al. 2001, Mäder et al. 2010).

Parasites of the genus Contracaecum Railliet et Henry, 1912 (Nematoda: Anisakidae) have several species of fish as intermediate or paratenic hosts, and piscivorous birds and mammals as definitive hosts (Anderson 2000). Contracaecum pelagicum (Johnston \& Mawson 1942) was first described in Australia in Diomedea melanophris (=Thalassarche melanophris) (Procellariiformes: Diomedeidae). Thereon, this parasite has been reported in several species of seabirds including penguins (Lent \& Freitas 1948, Portes-Santos 1984, Fagerholm et al. 1996, Silva et al. 2005). In 2001, Timi et al. reported third stage larvae of this worm in Engraulis anchoita, an important fish in the Magellanic penguins' diet.

The aim of this paper was to report the occurrence and pathological findings of Contracaecum pelagicum and $C$. plagiaticium Lent \& Freitas, 1948, in Magellanic penguins, Spheniscus magellanicus Foster, 1781, captured in Rio de Janeiro, Brazil.

\section{MATERIALS AND METHODS}

From July to September 2010, eleven young specimens of Magellanic penguins were investigated, regardless of sex, for helminthes in the digestive tract. Seven of them were obtained from different beaches in Rio de Janeiro, Brazil (22 $54^{\prime} 10^{\prime \prime} \mathrm{S}, 43^{\circ} 12^{\prime} 27^{\prime \prime} \mathrm{W}$ ). They were clinically followed up at the Niterói zoo, in Niterói city, Brazil ( $22^{\circ} 53^{\prime} 00^{\prime \prime} \mathrm{S}, 43^{\circ} 06^{\prime} 13^{\prime \prime} \mathrm{W}$ ), where they died. The remaining four birds were found dead on beaches in Búzios city, Brazil $\left(22^{\circ} 44^{\prime} 49^{\prime \prime} \mathrm{S}, 41^{\circ} 52^{\prime} 54^{\prime \prime} \mathrm{W}\right)$. All of penguins were submitted to post-mortem examination.

The necropsies were performed using the technique previously described by Zander et al. (1997). The digestive tract was opened and placed in Petri dishes containing a $0.85 \% \mathrm{NaCl}$ solution. Helminthes were fixed in acetic formaldehyde $90 \%$ of distilled water, $7 \%$ of pure formaldehyde and $3 \%$ of glacial acetic acid). Portions of the parasitized organs were removed and immediately fixed in $10 \%$ formaldehyde to be routinely processed for histo- pathology. Five-micrometer sections were stained with hematoxylin and eosin (HE).

Some nematodes were clarified in acetic acid P.A. and phenol P.A. and mounted unstained in balsam. Classification of nematodes followed Lent \& Freitas (1948) and Vicente et al. (1995) technique. Micrographs of some morphological characteristics were obtained with an Olympus BX-41 bright field microscope. The helminthes were deposited in the helminthological collection of the Instituto Oswaldo Cruz (CHIOC), number 35798 (C. plagiaticum) and 35799 (C. pelagicum).

This study was approved by the Ethics Committee on Animal Research of the Universidade Federal Fluminense ( $\mathrm{n}-215-10$ ) and licensed under $n$ o 23927-1, for activities with scientific purpose by the "Sistema de Autorização e Informação em Biodiversidade" (Sisbio/Ibama).

\section{RESULTS}

In the present study, six animals (54.54\%) were underweight with a palpable keel-shaped sternum and with a high prevalence of gastrointestinal helminthes $(100 \%)$. These animals (54.54\%) presented parasites in the stomach and esophagus. At the necropsy, gross lesions included hyperemia of the esophagus and/or stomach in six animals (54.54\%), all of which were in Niterói zoo. Three penguins $(27.27 \%)$ had only parasites in the stomach. The presence of parasites only in the esophagus was observed in only one animal $(9.09 \%)$, and the presence of parasites in the esophagus and small intestine simultaneously was likewise. Other macroscopic lesions found were pulmonary congestion, hepato- and splenomegaly. However, these findings are unspecific and thus impossible to be related to gastrointestinal parasitism. On histopathological examination, hyperemia of lungs, liver and spleen were found in all birds.

Determination of the number of parasites has not been carried out. However, the intensity of parasitic infection was macroscopically rated as low. For a correct classification of the species, at least ten male and ten female parasites were observed and measured.

Parasites were classified according to Lent \& Freitas (1948) and Vicente et al. (1995). The anterior end of adult worms consisted of three round lips (Fig.1), three interlabia and a nerve ring. The body showed a thick cuticle bearing transverse striations (Fig.1). In male worms, the elongated spicules were equal and the conical tail curved ventrally (Fig.2). In female, the uterus was sinuous with subglobular thick-shelled eggs.

For Contracaecum pelagicum, in the present study, the mean body length was $24.6 \mathrm{~mm}$ in males and $34.7 \mathrm{~mm}$ in females. The average width was $0.77 \mathrm{~mm}$ in males and 1.00 $\mathrm{mm}$ in females. The average size of the lips for males and females was $0.103 \mathrm{~mm}$ and $0.117 \mathrm{~mm}$, respectively. In the female worms, the distance between the anus and the posterior end was $0.40 \mathrm{~mm}$, and the spicules had an average size of $4.39 \mathrm{~mm}$ in males. As for the C. plagiaticium, the mean body length was $14.0 \mathrm{~mm}$ in males and $14.9 \mathrm{~mm}$ in females. A mean width of $0.55 \mathrm{~mm}$ was measured for both. The average size of the lips was $0.086 \mathrm{~mm}$ in males and $0.082 \mathrm{~mm}$ in females. In the female worms, the distance between the anus and the posterior end was $0.28 \mathrm{~mm}$, and the spicules had an average size of $3.50 \mathrm{~mm}$ in males. 


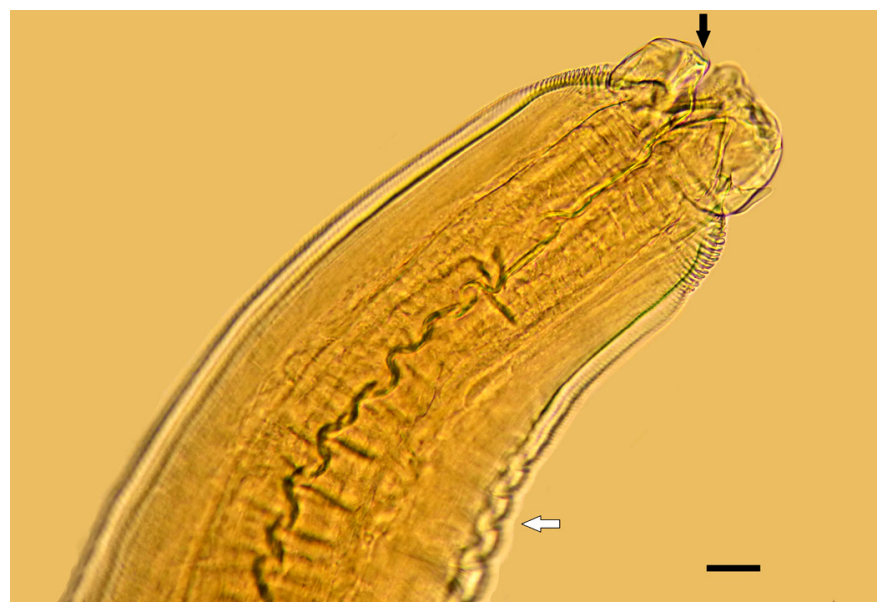

Fig.1. Anterior end of a male of Contracaecum pelagicum found in esophagus of Magellanic penguin (Spheniscus magellanicus), presenting three lips (black arrow) and transverse striations in cuticle (white arrow). Bar $=0.055 \mathrm{~mm}$

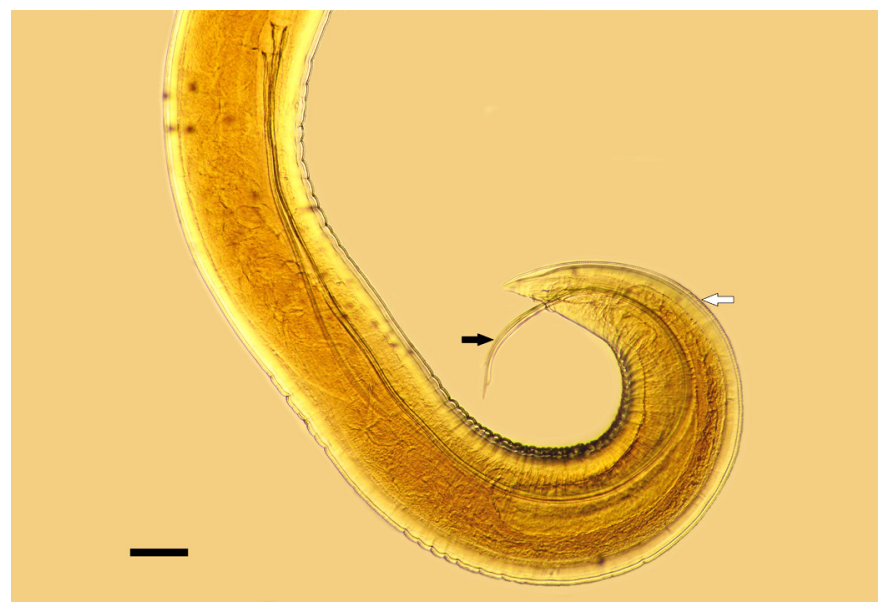

Fig.2. Posterior end of a male of Contracaecum plagiaticium found in esophagus of Magellanic penguin (Spheniscus magellanicus), presenting the equal elongate spicules (black arrow) and the conical tail curved ventrally (white arrow). Bar $=0.21 \mathrm{~mm}$

Contracaecum pelagicum and C. plagiaticium were observed in three $(27.27 \%)$ and in five $(45.46 \%)$ penguins respectively. Co-infections with Contracaecum pelagicum and C. plagiaticium were observed in three animals (27.27\%).

Among the three animals infected by $C$. pelagicum, one $(9.09 \%)$ was under treatment in the Niterói zoo, while the others were brought from Búzios city. In the cases of parasitism by C. plagiaticium, four animals $(36.36 \%)$ were under treatment in Niterói zoo. In addition, the Niterói zoo kept two $(18.18 \%)$ animals that had both species of the genus Contracaecum.

At the necropsy, one penguin $(9.09 \%)$ which was infected by C. plagiaticium, presented a hemorrhagic area in the gastric mucosa and on histopathological examination, two animals $(18.18 \%)$ presented esophagitis with helminthes segments inserted in the epithelium, showing discrete mixed inflammatory infiltrate of heterophils and mononuclear cells in smaller amounts (Fig.3 and 4). Both animals came from the Niterói zoo. One bird was parasitized by C. pelagicum and the other was parasitized by the two species of the parasite.

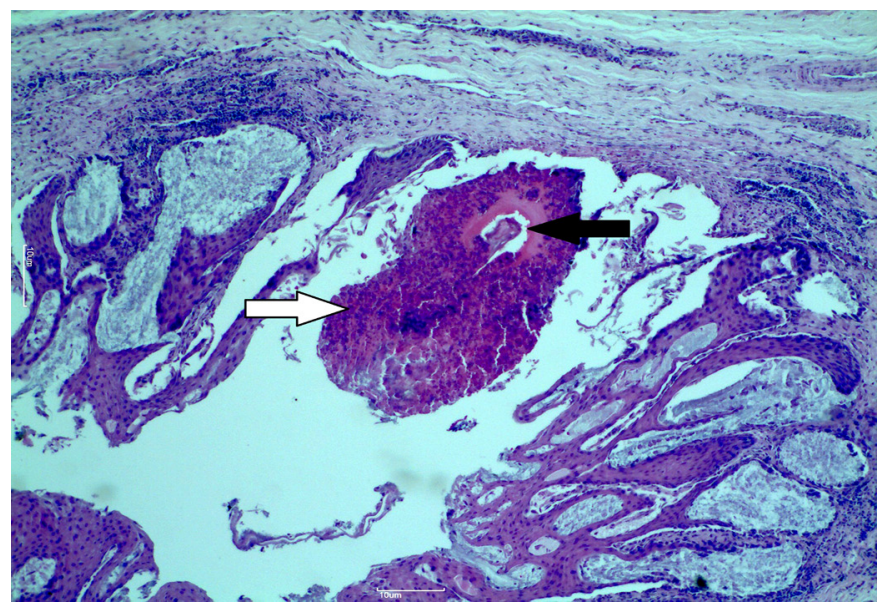

Fig.3. Histological section of the esophagus of Magellanic penguin (Spheniscus magellanicus) presenting a helminthic (black arrow) segment in the epithelium showing mixed inflammatory infiltrate (white arrow). HE, obj.10x.

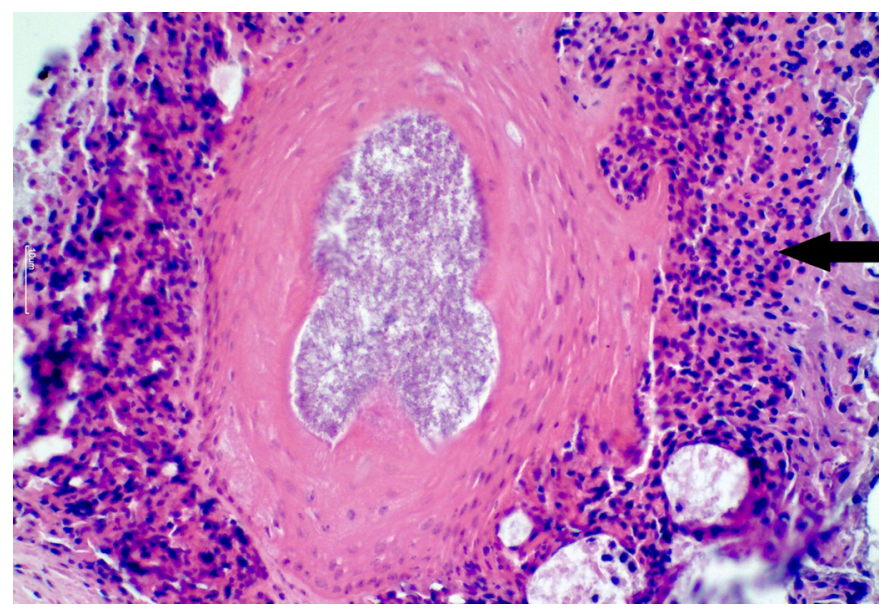

Fig.4. Detail of the histological section of the esophagus of Magellanic penguin (Spheniscus magellanicus) presenting a helminthic segment in the epithelium showing mixed inflammatory infiltrate (black arrow). HE, obj.40x.

A pink to bluish-pink hyaline material was formed deep in the gastric glands around the parasites. Secondary bacterial invasion and subsequent heterophil infiltration of the adjacent tissues were also noted in cross-sections of these two penguins.

\section{DISCUSSION}

In the present study, the underweightness and the palpable keel-shaped sternum observed were probably due to food privation (Rupley 1999). Gross lesions in animals infected by Contracaecum spp. differs from Ranum \& Wharton (1996). They have found no obvious evidence of damage by the helminthes in any of the alimentary tracts of the $\mathrm{Me}$ gadyptes antipodes in New Zeland. However, in 1971, Liu \& Edward reported the presence of Contracaecum spp. associated with gastric ulcers in Eumetopias jubatus and Pelecanus erythrorhynchos captured on the California coast. The ulcers were dark gray with their surfaces coated with mucus and their bases with a layer of necrotic tissue in which the heads of the parasites were buried. Although the pen- 
guins of this study did not have ulcers, a hemorrhagic area was observed in the stomach of one animal.

Obendorf \& McColl (1980), in a study about mortality in Eudyptula minor from the coast of Australia, identified emaciation and gastric ulcers as the major necropsy findings. For the authors, $77 \%$ of all penguins examined were judged to be in poor body condition. Ulcers, often associated with nematodes, were found in $67 \%$ of the birds. In that case, the parasite observed was Contracaecum spiculigerum.

The formation of the hyaline material around the nematodes in the stomach glands was not fully understood. However, it is suggested that this material results from secretion of the parasite mixed with necrotizing tissue and debris from the host, as already suggested by Liu \& Edward (1971) and by Obendorf \& McColl (1980). Secondary bacterial invasion and heterophil infiltration were also described by Liu \& Edward (1971) in Eumetopias jubatus and Pelecanus erythrorhynchos, and by Obendorf \& McColl (1980) in Eudyptula minor.

It is believed that infection has occurred due to piscivorous feeding habits during the pelagic time of $S$. magellanicus, since Contracaecum sp. have several species of fish as intermediate or paratenic hosts, including Engraulis anchoita, an important fish in the Magellanic penguins' diet (Timi et al. 2001).

Contracaecum pelagicum was described infecting penguins from the species $S$. magellanicus on the coast of Rio de Janeiro in 1984 (Portes-Santos 1984). The parasite $C$. rudolphii was described in Phalacrocorax olivaceus in Chile (Torres et al. 1982, 1991) and in the same country S. magellanicus was observed parasitized by Contracaecum sp. and $C$. pelagicum in its stomach and intestines (Pazos et al. 2003, González-Acuña et al. 2008). C. pelagicum was also found in S. magellanicus in Argentina (Garbin et al. 2007).

In Brazil, recent reports of parasitism by $C$. pelagicum include a study of Sula leucogaster in São Paulo State (Silva et al. 2005), one more case of $C$. pelagicum in one specimen of S. magellanicus in Espirito Santo State, southeastern coast of Brazil (Ederlil et al. 2009), and a study about the helminthic fauna of Magellanic penguins in São Paulo State (Prado et al. 2011). However, parasite diversity studies in this bird are scarce and the presence of $C$. plagiaticium has not been often described in S. magellanicus or on the Brazilian coast.

In the present study the cause of death was not fully elucidated. However, it was possible to conclude that Magellanic penguins are susceptible to gastrointestinal parasites and that at least two different species of the genus Contracaecum occur in birds captured on the coast of Rio de Janeiro State, thus they may be associated to other diseases, implicating in the death of these penguins.

Acknowledgments.- To Prof. Adriana Sudré, Universidade Federal Fluminense, Niterói/RJ, for the critical reading of the manuscript and for assistance regarding photomicrographs. To Grupo de Estudos de Mamíferos Marinhos da Região dos Lagos/ENSP/Fiocuz, for providing the penguins for analysis.

\section{REFERENCES}

Anderson R.C. 2000. Nematode parasites of vertebrates: Their development and transmission. $2^{\text {nd }}$ ed. Cabi Publishing, New York. 650p.
Boersma P.D. 2008. Penguins as marine sentinels. Bioscience 58:597-607.

Ederlil N.B., Oliveira F.C.R., Monteiro C.M., Silveira L.S. \& Rodrigues M.L.A. 2009. Ocorrência de Contracaecum pelagicum Johnston \& Mawson, 1942 (Nematoda, Anisakidae) em pinguim-de-magalhães (Spheniscus magellanicus Forster, 1781) (Aves, Spheniscidae) no litoral do Espírito Santo. Arq. Bras. Med. Vet. Zootec. 61:1006-1008

Ellis S. \& Branch S. (eds.). 1994. Penguin Husbandry Manual. Am. Zoo and Aquarium Assoc., Bethesda, MD. 134p.

Fagerholm H.P., Overstreet R.M. \& Humphery-Smith I. 1996. Contracaecum magnipapillatum (Nematoda, Ascaridoidea): Resurrection and pathogenic effects of a common parasite from the proventriculus of Anous minutus from the Great Barrier Reef, with a note on C. variegatum. Helminthologia 33:195-207.

Fonseca V.S.S., Petry M.V. \& Jost A.H. 2001. Diet of the Magellanic penguin on the coast of Rio Grande do Sul, Brazil. Waterbirds 24:290-293.

Garbin L.E., Navone G.T., Diaz J.I. \& Cremonte F. 2007. Further study of Contracaecum pelagicum (Nematoda: Anisakidae) in Spheniscus magellanicus (Aves: Spheniscidae) from Argentinean coasts. J. Parasitol. 93:143-150.

González-Acuña D., Kinsella J.M., Lara J. \& Valenzuela-Dellarossa G. 2008. Parásitos gastrointestinales en pingüino de Humboldt (Spheniscus humboldti) y pingüino de Magallanes (Spheniscus magellanicus) en las costas del centro y centro sur de Chile. Parasitologia Latino-Americana 63:5863

Lent H. \& Freitas J.F.T. 1948. Uma coleção de nematódeos, parasitos de vertebrados, do Museu de História Natural de Montevideo. Mem. Inst. Oswaldo Cruz 46:1-71.

Liu S.K. \& Edward A.G. 1971. Gastric ulcers associated with Contracaecum spp. (Nematoda: Ascaroidea) in a steller sea lion and a white pelican. J. Wildl. Dis. 7:266-271.

Mäder A., Sander M. \& Casa Jr G. 2010. Ciclo sazonal de mortalidade do pinguim-de-Magalhães, Spheniscus magellanicus influenciado por fatores antrópicos e climáticos na costa do Rio Grande do Sul, Brasil. Revta Bras. Ornitologia 18:228-233.

Obendorf D.L. \& McColl K. 1980. Mortality in little penguins (Eudyptula minor) along the coast of Victoria, Australia. J. Wildl. Dis. 16:251-260

Pazos G.E., Laurenti S. \& Díaz J.I. 2003. Helmintofauna del pinguino de Magallanes (Spheniscus magellanicus) em península Valdes, província del Chubut: resultados preliminares. Historia Natural 2:85-94.

Portes-Santos C. 1984. Um nematódeo parasita do pinguim Spheniscus magellanicus (Foster) (Ascaridoidea, Anisakidae). Mem. Inst. Oswaldo Cruz 79:233-237.

Prado M.I.B.M., Santos-Lopes A.R. \& Silva R.J. 2011. Helminthfauna of Magellanic penguin (Spheniscus magellanicus Foster 1781) proceeding from Ilha Comprida, south coast, state of São Paulo, Brazil. Neotrop. Helminthol. 5 (1): 50-55

Ranum A. \& Wharton D.A. 1996. Helminth and protozoan parasites of the alimentary tract of the yellow-eyed penguin (Megadyptes antipodes). $\mathrm{N}$. Z. J. Zoology 23:83-87.

Ruoppolo V., Adornes A.C., Nascimento A.C. \& Silva Filho R.P. 2004. Reabilitação de pingüins afetados por petróleo. Clínica Veterinária 51(9):7883.

Rupley A.E. 1999. Manual de Clínica Aviária. Roca, São Paulo. 598p.

Serafini P.P., Gomes A.L.M., Maranho A., Fernandes A., Mader A., Altiere B.L., Matias C.A.R., Niemeyer C., Kolesnikovas C.K.M., Guerra F., Dantas G.P.M., Vivekananda G., Nunes G.T., Oberg I., Simao Neto I., Fausto I.V., Araujo J., Catao-Dias J.L., Barros J.A., Cardoso L.G., Barbosa L.A., Duarte M.V., Barragana M., Labarthe N., Baldassin P., Maracini P., Vanstreels R.E.T., Velozo R.S., Silva-Filho R.P., Freitas R.R., Campos S.D.E., Serra S.D., Raso T.F., Muraoka T.R., Garcia T.F., Ruoppolo V. \& Carniel V.L. 2010. Projeto Nacional de Monitoramento de Pinguim-de-Magalhães (Spheniscus magellanicus). CEMAVE (ICMBio), Brasília. 36p.

Silva R.J., Raso T.F., Faria P.J. \& Campos F.P. 2005. Occurrence of Contracaecum pelagicum Johnston \& Mawson 1942 (Nematoda, Anisakidae) in Sula leucogaster Boddaert, 1783 (Pelecaniformes, Sulidae). Arq. Bras. Med. Vet. Zootec. 57:565-567. 
Silva Filho R.P. \& Ruoppolo V. 2007. Sphenisciformes (Pingüim), p.309323. In: Cubas Z.S., Silva J.C.R. \& Catão-Dias J.L. (Eds), Tratado de Animais Selvagens. Roca, São Paulo. 1354p.

Timi J.T., Sardella N.H. \& Navone G.T. 2001. Parasitic nematodes of Engraulis anchoita (Pisces: Engrauliidae) from the Argentine and Uruguayan Seas. Acta Parasitologica 46:186-193.

Torres P., Figueroa L., Saldivia A. \& Barrientos J. 1982. Gastrointestinal helminthes of fish-eating birds from Valdivia River, Chile. J. Parasitol. 68:1157.
Torres P., Ruiz E., Gesche W. \& Montefusco A. 1991. Gastrointestinal helminthes of fish-eating birds from Chiloe Island, Chile. J. Wildl. Dis. 27:178-179

Vicente J.J., Rodrigues H.O., Gomes D.C. \& Pinto R.M. 1995. Nematóides do Brasil. Parte IV: nematóides de aves. Revta Bras. Zoologia 12(Supl.1):1-273.

Zander D.V., Bermudez A.J. \& Mallinson E.T. 1997. Principles of disease prevention: diagnosis and control, p.3-45. In: Calnek B.W., Barnes H.J., Beard C.W., McDougald L.R. \& Saif Y.M. (Eds), Diseases of Poultry. $10^{\text {th }} \mathrm{ed}$. Iowa State University Press, Ames. 1080p. 